\title{
Research on Damage Assessment of Concrete-Filled Steel Tubular Column Subjected to Near-Field Blast Loading
}

\author{
Ying Cui, ${ }^{1}$ Meimei Song, ${ }^{1}$ Zhan $Q u,{ }^{1}$ Shanshan Sun, ${ }^{2}$ and Junhai Zhao $\mathbb{D}^{2}$ \\ ${ }^{1}$ School of Mechanical Engineering, Xi'an Shiyou University, Xi'an 710065, China \\ ${ }^{2}$ School of Civil Engineering, Chang'an University, Xi'an 710061, China \\ Correspondence should be addressed to Junhai Zhao; zhaojh@chd.edu.cn
}

Received 1 June 2020; Revised 8 September 2020; Accepted 3 November 2020; Published 23 November 2020

Academic Editor: Giosuè Boscato

Copyright (c) 2020 Ying Cui et al. This is an open access article distributed under the Creative Commons Attribution License, which permits unrestricted use, distribution, and reproduction in any medium, provided the original work is properly cited.

Concrete-filled steel tubular (CFST) columns are widely used in engineering structures, and they have many different cross section types. Among these, normal solid sections and concrete-filled double-skin steel tubular sections are often used. Although many studies have been conducted on CFST columns with these two section types, no studies have been conducted on their damage assessment under blast loading. In this study, experimental analysis and a numerical simulation method were integrated to evaluate the responses and assess the damage of two concrete-filled steel tubular (CFST) columns with different cross sections subjected to near-field blast loading. The results showed that for a scaled distance of $0.14 \mathrm{~m} / \mathrm{kg}^{1 / 3}$, plastic bending deformation occurred on the surfaces of the two CFST columns facing the explosive. The antiexplosion performance of the normal solid-section (NSS) CFST column was better than that of the concrete-filled double-skin steel tubular (CFDST) column. The explosion centre was set at the same height as the middle of column, and the distributions of the peak pressure values of the two columns were similar: the peak pressures at the middle points of the columns were the greatest, and the peak pressures at the bottom were higher than those at the top. With the analysis of the duration of the positive pressure, the damage at the middle was the most severe when subjected to blast loading. Using pressure-impulse damage theory and the validated numerical simulations, two pressure-impulse damage evaluation curves for NSS and CFDST columns were established separately by analysing the experimental and simulation data. Finally, based on the two pressure-impulse damage evaluation curves, the two pressure-impulse damage criteria for these two different fixed-end CFST columns were defined based on the deflection of the surfaces facing the explosives. Furthermore, the mathematical formulae for the two different column types were established to generate pressure-impulse diagrams. With the established formulae, the damage of the CFST columns with these two cross section types can be evaluated. Damage to other similar CFST columns with different cross section types due to near-field blast loading can also be evaluated by this method.

\section{Introduction}

Concrete-filled steel tubular (CFST) columns are widely used in engineering structures because of their high bearing capacities, good plasticities, and high flexural stiffnesses, and their static mechanical properties have been researched widely. Since a column is a vertical bearing member, many researchers have focused on the characteristics of CFST columns under axial loading. Huang et al. researched the deformation mechanisms of concrete-filled double-skin steel tubular (CFDST) columns under axial loading and determined the load bearing properties of the inner steel tube, outer steel tube, and concrete [1]. The influences of the cross-sectional parameters on the ultimate bearing capacities of hollow concrete-filled steel tubular columns under axial loading and the effect of the hollow ratio on the stress-strain relation was analysed by Wang et al. [2]. Güneyisi et al. developed an effective prediction model by means of gene expression programming to evaluate the axial load carrying capacities of short CFST columns [3]. Based on the results of tests conducted by various researchers on 213 samples, two theoretical equations were derived for the prediction of the ultimate axial load strengths of CFST columns by Kumar et al. [4]. Li et al. implemented axial compression experiments of short CFST columns with 18 different parameters and proposed a series 
of formulae to calculate the carrying capacities of these columns [5]. Ou and Shao studied the static strength of a short circular CFST column strengthened with a carbonfibre-reinforced polymer (CFRP) theoretically and established equations for calculating the yield strength and the ultimate strength of this type of column under axial compression [6]. Hossain and Chu developed a modified model to predict the strengths of confined concrete in CSFT columns with different shapes and slenderness values using axial compression experiments [7]. Some scholars have tried to use a static mechanics method (i.e., the singledegree-of-freedom method (SDOF)) to describe the dynamic characteristics of CFST columns [8]. In summary, scholars have conducted many studies on the static mechanical performances of CFST columns. However, due to the frequent occurrence of explosion accidents and terrorist attacks in the world, the possibility of conventional building structures being impacted by explosions is increasing. Thus, the dynamic characteristics and explosion resistance performance of CFST columns should be more of a focus than ever before. Furthermore, an effective damage assessment method for CFST columns subjected to blast loading is needed. In recent years, researchers have studied the dynamic responses of columns under explosion shocks and achieved many results. The relevant studies can be divided into three categories:

(1) Studies of the dynamic bending characteristics of a defective simply supported column made of reinforced concrete or steel subjected to blast loading by numerical simulations and experimental analyses [9-12]. Hao et al. investigated the elastic-plastic dynamic buckling of steel columns subjected to underground explosions, and the corresponding critical peak particle velocities of ground vibrations were determined for each column [9]. Lim et al. studied the effects of different reinforcing methods in beam-column joints on the blast resistance, and they found that the use of diagonal reinforcement in the joints was the most effective method for enhancing the resistance under blast loads [10]. Thairy proposed a modified approach to the SDOF analysis method of axially loaded steel columns under blast loads, and this method was proven to be valid [11]. Considering the strain softening behaviour of concrete, $\mathrm{Li}$ et al. developed two numerical examples using a nonlocal damage model, and the results indicated that both cases produced objective response in the postpeak stage [12].

(2) Studies of the dynamic responses, antiexplosion performances, failure modes, and the corresponding influence factors of reinforced concrete columns and CFST columns under blasting and impact loads [13-21]. Using the AUTODYN-3D software, Ma et al. investigated the dynamic responses of circular concrete-filled steel tubes with different cross sections under blast loading and proved that the steel casing could effectively reduce the intensity of the explosion stress wave [13]. Shi conducted a thorough study on the dynamic responses and damage mechanism of reinforced concrete structures under blast loading and determined the possible failure modes of reinforced concrete columns. A new damage criterion for reinforced concrete columns was defined based on the residual axial load carrying capacities of the columns [14]. Xue et al. implemented explosion experiments on CFST specimens with the same diameter and different wall thicknesses. They found that improving the casing hoop steel coefficient of CFST structures could enhance the antiexplosion abilities [15]. Cui et al. researched the pressure distributions of blast waves on the surfaces of CFST columns by conducting explosion tests. Furthermore, based on the results of the explosion tests, reasonable mesh sizes for the air and explosive regions in numerical simulations were proposed [16]. Xu et al. conducted a field blast test including six specimens. Using the results of the tests and an FEM procedure, the blast resistance performances of ultra-high performance steel-fibre-reinforced concrete-filled double-skin steel tubular columns were determined under conditions with various design parameters [17]. Nica et al. focused on the numerical analysis of collapse due to blast action for a reinforced concrete framed building. They proposed an applied element method for their numerical simulations, which was proven to be effective by comparing with experimental data [18]. Chen et al. investigated the influences of the scale standoff distance and fire duration on the dynamic responses and failure modes of reactive-powder concrete-filled steel tubular column specimens under constant axial forces. They found that the blast resistance capacities of reactive-powder concrete-filled steel tubular columns were more sensitive to the fire duration than the scale standoff distances [19]. With an FEM procedure and explosion tests, Sun et al. determined the failure modes, residual deformation, and overpressure distribution of CFST columns with different cross sections [20]. Liu et al. studied the blast performances of steel-reinforced concrete beams experimentally. An empirical expression was developed via dimensional analysis to correct the relationship between the mid-span displacement and the scaled distance [21].

(3) Studies of the carrying capacity evaluation of CFST columns subjected to blast waves [22-25]. Zhang et al. presented an experimental study on the residual behaviours of ultra-high-performance concreteinfilled double-skin steel tubular columns after close range blast loading. It was found that the CFDST columns with smaller permanent displacements had larger peak residual axial capacities, and the CFDST columns that were not subjected to axial loads during the blast test exhibited more ductile behaviours than those that were axially loaded [22]. Wang et al. obtained the residual bearing capacities of concrete-filled steel 
tubular columns under blast loading by explosion tests. A circular concrete-filled steel tubular column had better ductility than a square concrete-filled steel tubular column [23]. Chen et al. conducted a series of blast resistance and load carrying capacity tests on six large-scale reactive-powder concrete-filled steel tubular columns to validate the suitability of the theoretical method that they presented. They found that the blast resistances of the reactive-powder concrete-filled steel tubular columns were more sensitive to the fire duration than to the scale distance [24]. Zou et al. developed an equivalent single-degree-of-freedom (SDOF) model to predict the residual carrying capacities of firedamaged reactive-powder concrete-filled steel tubular (RPC-FST) columns under axial lateral blast loads [25].

Although researchers have conducted many effective studies on the dynamic responses or failure modes of columns and other members under explosion shocks, studies on how to evaluate the safety of columns subjected to blast loading are still limited [26-28], especially CFST columns. Damage assessment of CFST columns subjected to blast loading is related to the safety of many structures. The study of concrete-filled steel tubular columns with different cross sections under near-field blast loading (distances no greater than twenty times the charge radius [29]) is especially important. Therefore, it is of great importance to investigate the damage effects of CFST columns under explosion shocks and to establish an effective and convenient damage assessment method.

In this paper, with an explosion experiment and numerical simulations, the dynamic responses of normal solidsection (NSS) CFST and concrete-filled double-skin steel tubular (CFDST) columns subjected to blast loading were numerically simulated based on the experimental results of the two types of CFST columns under blast loading. Focusing on the two key parameters, pressure and impulse, which mainly determine the damage of a target under blast loading, pressure-impulse damage theory is adopted. In this theory, if pressure and impulses coming from explosion shock waves meet the critical damage criterion of the target, it means that the target is damaged. Pressure-impulse damage theory can be described as follows [30]:

$$
\left(P-P_{\mathrm{Cr}}\right)\left(I-I_{\mathrm{Cr}}\right)=C \text {, }
$$

where $P_{\mathrm{cr}}$ is the critical value of the pressure causing a certain amount of damage to the target, $I_{\mathrm{cr}}$ is the critical value of the impulse causing a certain amount of damage to the target, and $C$ is a constant that is related to the characteristics and the damage level of the target.

Based on pressure-impulse damage theory and considering the deformation characteristics of specimens, an effective damage assessment criterion and corresponding formula for the two CFST column types were also established.

\section{Methods}

To evaluate the damage of CFST columns with different cross sections under near-field blast loading, two typical CFST column specimens-one with a normal solid section and one with a composite hollow section (i.e., the CFDST column)were selected and designed. Meanwhile, a near-field blasting experiment was designed and performed so that the dynamic responses and damage of the CFST columns could be investigated thoroughly.

\subsection{Experiment Design and Implementation}

2.1.1. Specimen Design. The parameters of the specimens were selected based on the Welded and Seamless Wrought Steel Pipe Standard (B36.10M-2018) and the Design of Composite Steel and Concrete Structures Standard (Euro code 1994-1-1:2004); the details are as follows. The outer diameter of the NSS CFST column, which was made of steel pipe, was $273 \mathrm{~mm}$. The thickness of the steel pipe was $7 \mathrm{~mm}$. The steel pipe was filled with fine-aggregate concrete whose compressive strength was C40. The outer diameter and thickness of the CFDST column were the same as those of the NSS column. However, there was an inner steel pipe whose outer diameter and thickness were 50 and $3 \mathrm{~mm}$, respectively, inside the CFDST column. Between the outer and inner steel pipes, there was C40 fine-aggregate concrete. The cross sections of the two columns are shown in Figure 1.

The bases of the two specimens were designed to be fixed. Steel ribbed plates were welded on the columns and baseplates. The size of the fillet weld was at least $10 \mathrm{~mm}$ to maintain a firm connection. The parameters of the specimens are listed in Table 1. The specimens are shown in Figure 2. Photographs of the steel specimens are shown in Figure 3, and the corresponding material properties are listed in Table 2.

To avoid local buckling of the column, based on the guidelines for circular hollow steel sections in the standard (Euro code 1994-1-1:2004), the ratio of diameter to thickness should not exceed the following maximum value:

$$
\max \left(\frac{d}{t}\right)=90 \frac{235}{f_{y}},
$$

where $d$ is the outer diameter of the circular hollow steel section, $t$ is the thickness of the tube wall, and $f_{y}$ is the yield strength of the steel tube.

According to equation (2), the diameter-to-thickness ratios of the two specimens were 39 and satisfied this requirement.

2.2. Experimental Conditions. To investigate the real dynamic responses and damage of two kinds of CFST columns under blast loading, an explosion experiment under the same constraint conditions was carried out. The basic test parameters were as follows. TNT was selected as the explosive, and $50 \mathrm{~kg}$ was used in the experiments. The distance between the explosion centre and column surface was $0.5 \mathrm{~m}$ (scaled distance was $0.14 \mathrm{~m} / \mathrm{kg}^{1 / 3}$ ).

The baseplates of the two columns were fixed by highstrength expansion bolts on a precast reinforced concrete board, which was buried in soil. The tops of the two columns 


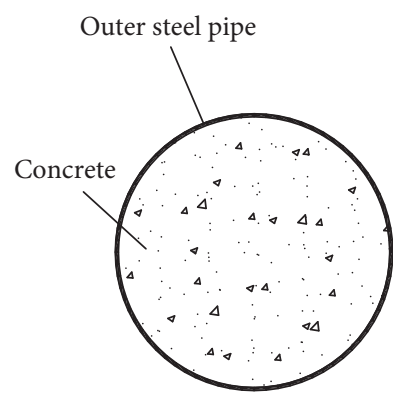

(a)

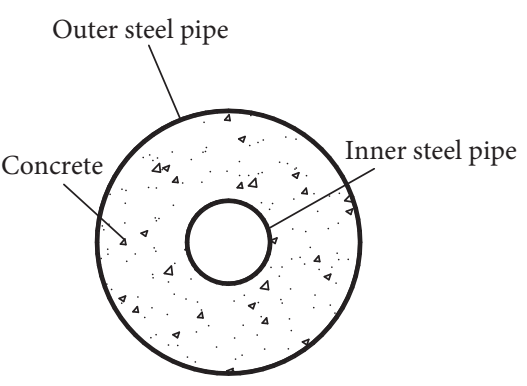

(b)

FIgure 1: Cross sections of columns. (a) NSS. (b) CFDST section.

TABLE 1: Design parameters of concrete-filled steel tubular columns.

\begin{tabular}{lcccccccc}
\hline Section & $\begin{array}{c}\text { Height } \\
(\mathrm{mm})\end{array}$ & $\begin{array}{c}\text { Diameter } \\
\text { of outer } \\
\text { steel pipe } \\
(\mathrm{mm})\end{array}$ & $\begin{array}{c}\text { Thickness } \\
\text { of outer } \\
\text { steel pipe } \\
(\mathrm{mm})\end{array}$ & $\begin{array}{c}\text { Diameter of } \\
\text { inner steel pipe } \\
(\mathrm{mm})\end{array}$ & $\begin{array}{c}\text { Section } \\
\text { inner steel pipe } \\
(\mathrm{mm})\end{array}$ & $\begin{array}{c}\text { Dimensions } \\
\text { of baseplate } \\
(\mathrm{mm})\end{array}$ & $\begin{array}{c}\text { Dimensions } \\
\text { of ribbed plate } \\
(\mathrm{mm})\end{array}$ & $\begin{array}{c}\text { Strength grade } \\
\text { of concrete }\end{array}$ \\
\hline NSS & 1800 & 273 & 7 & None & NSS & None & $600 \times 600 \times 30$ & $150 \times 300 \times 30$ \\
CFDST & 1800 & 273 & 7 & 50 & CFDST & 3 & $600 \times 600 \times 30$ & $150 \times 300 \times 30$ \\
\hline
\end{tabular}

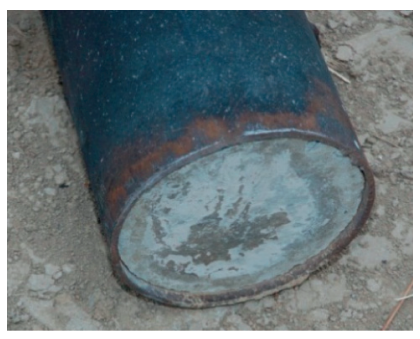

(a)

FIgURE 2: Photographs of specimens. (a) NSS.

were fixed by high-strength expansion bolts and professional reaction frames. The professional reaction frames were fixed on the buried reinforced concrete board by high-strength expansion bolts. A schematic diagram for the arrangement of the experiment is shown in Figure 4. To imitate a nearfield explosion, the explosive was placed at half of the column height, and the distance between the explosion centre and column surface was $0.5 \mathrm{~m}$. The corresponding scaled distance was $0.14 \mathrm{~m} / \mathrm{kg}^{1 / 3}$. A photograph of the test site is shown in Figure 5.

2.3. Experimental Results. The detonation moment captured using a high-speed camera is shown in Figure 6. The fireball zone was evident. Under the near-field blast loading with a scaled distance of $0.14 \mathrm{~m} / \mathrm{kg}^{1 / 3}$, significant plastic deformation occurred on the front middle surfaces of the two kinds of CFST columns. Furthermore, the fireball zone of the near-field explosion created burn marks on the front

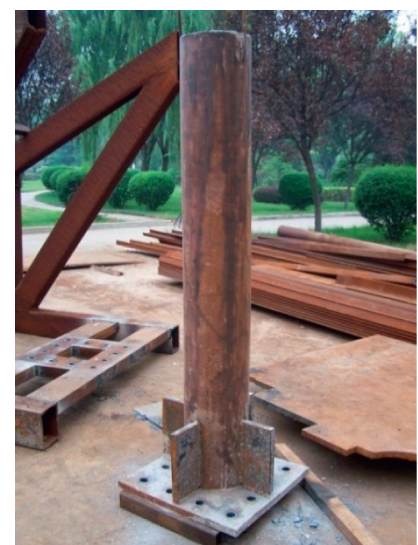

(c) (b)

(b) CFDST section. (c) Overall image of column.

surfaces of the columns, and no perforations were present. However, significant plastic deformation occurred on the front surfaces of the two columns under the near-field blast loading.

To quantify the plastic deformation, the deflection amounts of the surfaces facing the explosive were measured. The deflection amount of the CFDST column was $195 \mathrm{~mm}$ and that of the NSS CFST column was $135 \mathrm{~mm}$. Photographs of the macroscopic deformation of the two columns under the near-field blast loading are shown in Figure 7. Since the plastic deformation of the specimens crushed the inner concrete, concrete fragments would be ejected during the cutting process of the outer steel tube. Due to the safety concerns, the two column specimens were not cut open.

2.4. Numerical Simulations. To investigate the antiexplosion performance thoroughly and establish a scientific damage assessment method for the two kinds of CFST columns, a 


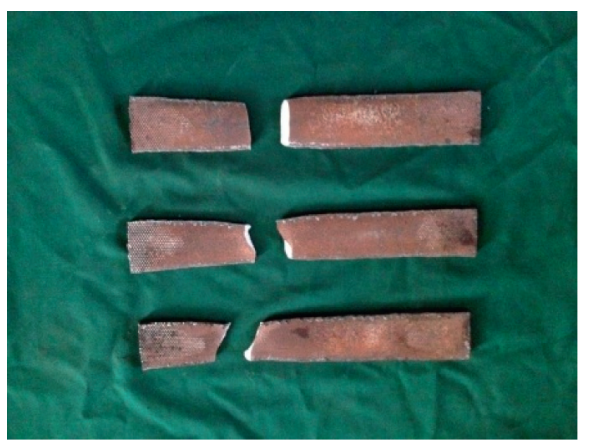

(a)

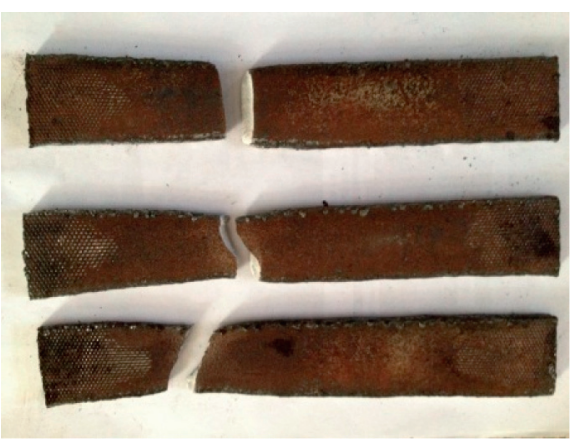

(b)

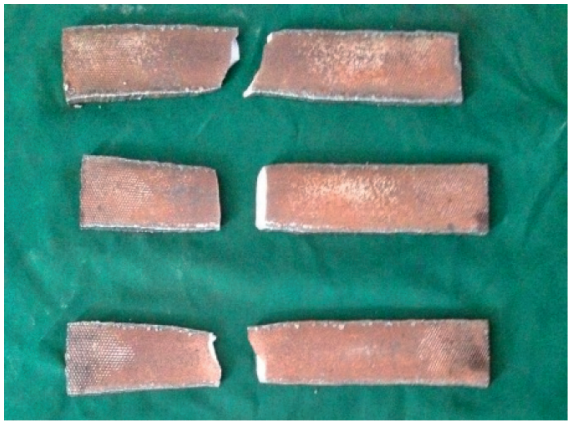

(c)

FIGURE 3: Photographs of steel specimens. (a) Outer pipe steel specimens. (b) Inner pipe steel specimens. (c) Base plate and ribbed plate steel specimens.

TABLE 2: Steel properties.

\begin{tabular}{|c|c|c|c|c|c|c|c|c|c|c|}
\hline Steel member & & & Test & valu & les $(\mathrm{M}$ & APa) & & Average value $(\mathrm{MPa})$ & Elastic modulus (MPa) & Elongation (\%) \\
\hline Outer pipe & $\begin{array}{l}\text { Yield strength } \\
\text { Ultimate strength }\end{array}$ & $\begin{array}{l}285 \\
420\end{array}$ & $\begin{array}{l}300 \\
415\end{array}$ & $\begin{array}{l}295 \\
410\end{array}$ & $\begin{array}{l}305 \\
435\end{array}$ & $\begin{array}{l}290 \\
420\end{array}$ & $\begin{array}{l}280 \\
420\end{array}$ & $\begin{array}{c}292.5 \\
420\end{array}$ & 208 & 26.2 \\
\hline Inner pipe & $\begin{array}{l}\text { Yield strength } \\
\text { Ultimate strength }\end{array}$ & $\begin{array}{l}320 \\
330\end{array}$ & $\begin{array}{l}250 \\
350\end{array}$ & $\begin{array}{l}385 \\
385 \\
\end{array}$ & $\begin{array}{l}375 \\
530\end{array}$ & $\begin{array}{l}245 \\
335\end{array}$ & $\begin{array}{l}220 \\
305\end{array}$ & $\begin{array}{l}299.1 \\
372.5 \\
\end{array}$ & 193 & 29.3 \\
\hline $\begin{array}{l}\text { Base plate and } \\
\text { ribbed plate }\end{array}$ & $\begin{array}{l}\text { Yield strength } \\
\text { Ultimate strength }\end{array}$ & $\begin{array}{l}420 \\
555 \\
\end{array}$ & $\begin{array}{l}425 \\
550\end{array}$ & $\begin{array}{l}360 \\
490 \\
\end{array}$ & $\begin{array}{l}400 \\
540\end{array}$ & $\begin{array}{l}340 \\
480\end{array}$ & $\begin{array}{l}335 \\
475 \\
\end{array}$ & $\begin{array}{l}380 \\
515 \\
\end{array}$ & 220 & 22.1 \\
\hline
\end{tabular}

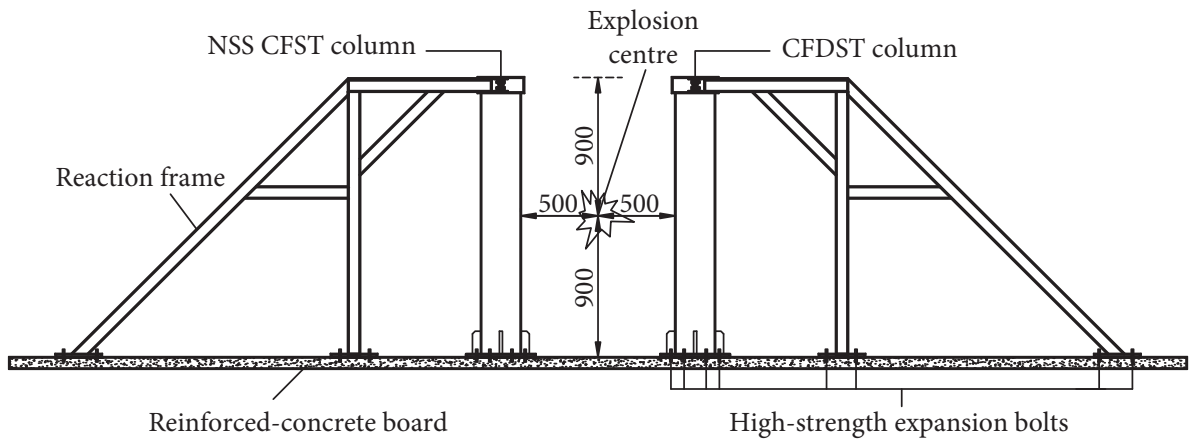

Figure 4: Schematic diagram of test site (unit: $\mathrm{mm}$ ). 


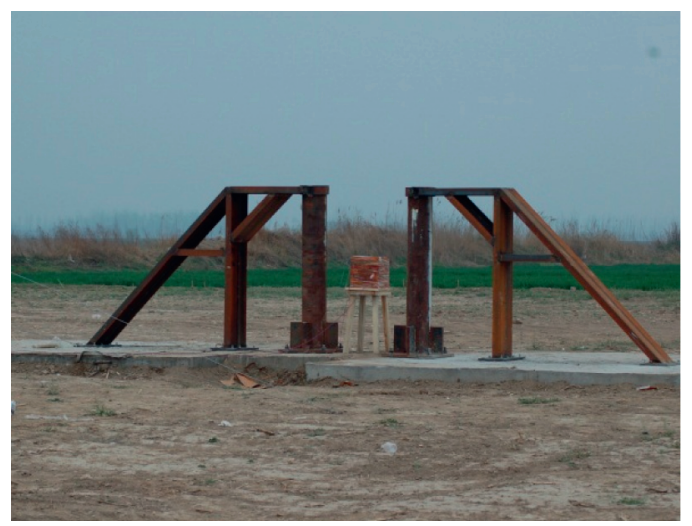

FIGURE 5: Photograph of test site.

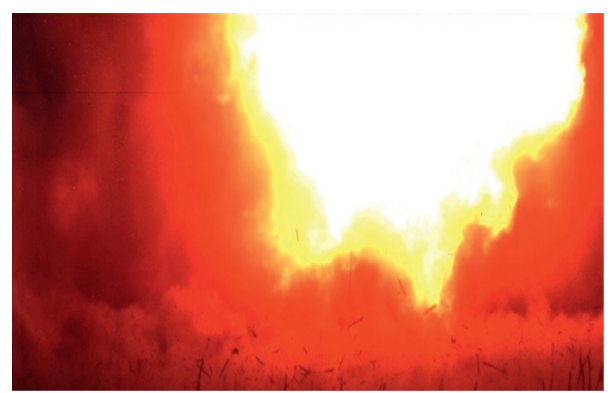

FIgURE 6: Photograph of explosion.

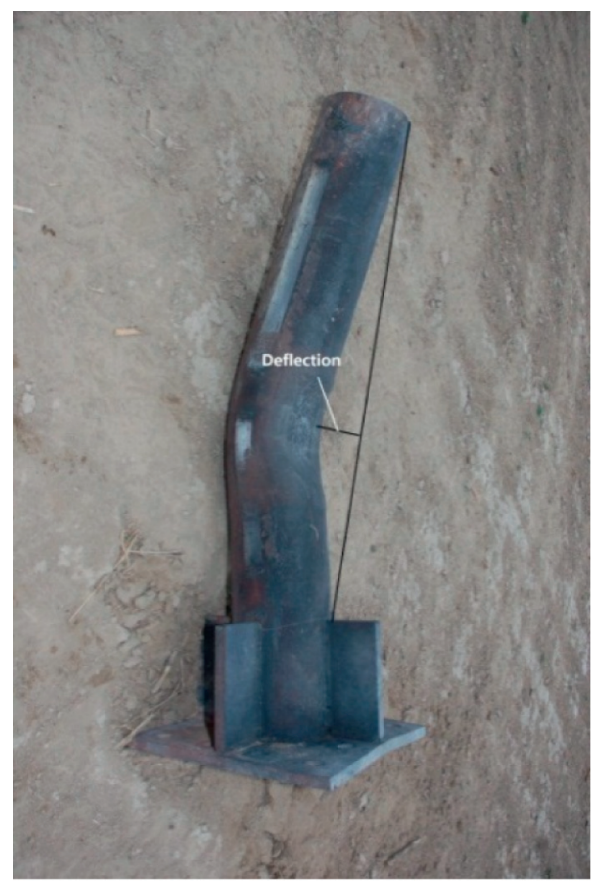

(a)

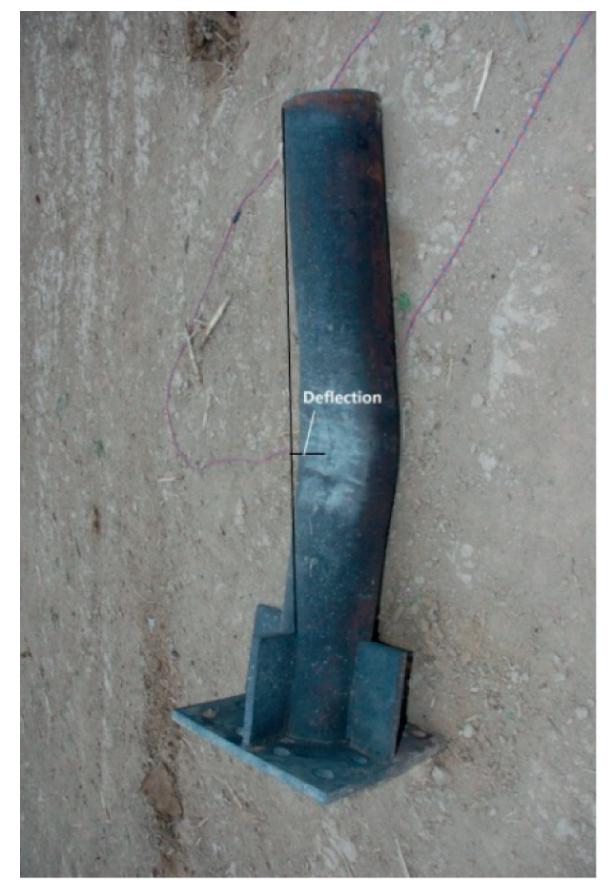

(b)

Figure 7: Macroscopic deformation of two CFST columns. (a) CFDST section. (b) NSS. 
TABLE 3: Parameters of *MAT_JOHNSON_HOLMGUIST_CONCRETE (card1).

\begin{tabular}{lcccccccc}
\hline Parameters & MID & RO & $G$ & $A$ & $B$ & $C$ & $N$ & FC \\
\hline Value & 1 & $2.4 \times 10^{-3}$ & 14860 & 0.79 & 1.60 & 0.007 & 0.61 & 45 \\
\hline
\end{tabular}

TABLE 4: Parameters of *MAT_JOHNSON_HOLMGUIST_CONCRETE (card2).

\begin{tabular}{lllcccccc}
\hline Parameters & $T$ & EPS0 & EFMIN & SFMAX & PC & UC & PL & UL \\
\hline Value & 4 & 0.001 & 0.01 & 7 & 15 & 0.001 & 800 & 0.1 \\
\hline
\end{tabular}

TABle 5: Parameters of *MAT_JOHNSON_HOLMGUIST_CONCRETE (card3).

\begin{tabular}{lcccccc}
\hline Parameters & $D_{1}$ & $D_{2}$ & $K_{1}$ & $K_{2}$ & $K_{3}$ & FS \\
\hline Value & 0.04 & 1.0 & 85000 & -171000 & 208000 & 0.0 \\
\hline
\end{tabular}

TABLE 6: Parameters of *MAT_PLASTIC_KINEMATIC (card1).

\begin{tabular}{lccccccc}
\hline Parameters & MID & RO & $E$ & PR & SIGY & ETAN & BETA \\
\hline Value & 2 & $7.83 \times 10^{-3}$ & $2.1 \times 10^{5}$ & 0.3 & 292.5 & $2.1 \times 10^{3}$ & 0.0 \\
\hline
\end{tabular}

TABle 7: Parameters of *MAT_PLASTIC_KINEMATIC (card2).

\begin{tabular}{lcccc}
\hline Parameters & SRC & SRP & FS & \\
\hline Value & 40 & 5 & 0.2 & VP \\
\hline
\end{tabular}

TABle 8: Parameters of *MAT_HIGH_EXPLOSIVE_BURN (card1).

\begin{tabular}{lcccccccc}
\hline Parameters & MID & RO & $D$ & PCJ & BETA & $K$ & $G$ & SIGY \\
\hline Value & 4 & $1.64 \times 10^{-3}$ & $6.93 \times 10^{3}$ & $2.1 \times 10^{4}$ & 0.0 & 0.0 & 0.0 & 0.0 \\
\hline
\end{tabular}

TABle 9: Parameters of * MAT_NULL (card1).

\begin{tabular}{lcccccccc}
\hline Parameters & MID & RO & PC & MU & TEROD & CEROD & YM & PR \\
\hline Value & 3 & $1.29 \times 10^{-6}$ & 0.0 & 0.0 & 0.0 & 0.0 & 0.0 & 0.0 \\
\hline
\end{tabular}

numerical model was established in the LS-DYNA software based on the explosion experiment results, and finite element numerical simulations were carried out.

2.5. Constitutive Model of Material. The CFST columns, air, and explosive were numerically simulated using SOLID164 cell elements $[31,32]$. The corresponding unit system was mm-ms-MPa.

2.5.1. Constitutive Model of Concrete. In the LS-DYNA material selector, material no. 111 ( ${ }^{*}$ MAT_JOHNSON_HOLMGUIST_CONCRETE) was selected to simulate the dynamic behaviour of concrete under high strain rates. The corresponding parameters of this constitutive model are shown in Tables 3-5.

2.5.2. Constitutive Model of Steel. In the LS-DYNA material selector, material no. 3 ( ${ }^{*}$ MAT_PLASTIC_KINEMATIC) was selected to simulate the dynamic behaviour of the steel under high strain rates. The corresponding parameters of this constitutive model are shown in Tables 6 and 7.
2.5.3. Constitutive Model of Explosives and Air. A highenergy explosive combustion model of the high explosive in the LS-DYNA software, ${ }^{*}$ MAT_HIGH_EXPLOSIVE_ BURN, was used to simulate the detonation of the TNT explosive, and the material model *MAT_NULL was used to simulate the air. The parameters of these two constitutive models are shown in Tables 8 and 9, respectively.

2.6. State Equation of Material. In LS-DYNA, the constitutive model and the state equation were used to describe the properties of the fluid materials, i.e., the explosives and air. A constitutive model was chosen to describe the relationship between the stress $\Delta \sigma_{i j}$ and strain $\Delta \varepsilon_{i j}$. A state equation was selected to describe the relationship between the volume deformation rate $\Delta V / V$ and the pressure $\Delta P$ for the air and the explosives.

2.6.1. State Equation of Explosive. The *EOS_JWL model in LS-DYNA was used to predict the pressure produced in the explosion process, and the predictions were similar to the experimental results. The *EOS_JWL model is based on the 
TABle 10: Parameters of state equation of explosive.

\begin{tabular}{lcccccccc}
\hline Parameters & EOSID & $A$ & $B$ & $R_{1}$ & $R_{2}$ & OMEG & $E_{0}$ & $V_{0}$ \\
\hline Value & 4 & $3.74 \times 10^{5}$ & $3.23 \times 10^{3}$ & 4.15 & 0.95 & 0.3 & 7000 & 1.0 \\
\hline
\end{tabular}

TABLE 11: Parameters of state equation of air.

\begin{tabular}{lcccccccccc}
\hline Parameters & EOSID & $C_{0}$ & $C_{1}$ & $C_{2}$ & $C_{3}$ & $C_{4}$ & $C_{5}$ & $C_{6}$ & $E_{0}$ & $V_{0}$ \\
\hline Value & 3 & 0.0 & 0.0 & 0.0 & 0.0 & 0.4 & 0.4 & 0.0 & 0.25 & 1.0 \\
\hline
\end{tabular}

Jones-Wilkens-Lee equation of state, which is often used to describe the detonation of explosives [31]:

$$
P=A\left(1-\frac{w}{R_{1} V}\right) e^{-R_{1} V}+B\left(1-\frac{w}{R_{2} V}\right) e^{-R_{2} V}+\frac{w E}{V}
$$

where $P$ is the detonation pressure, $V$ is the relative volume, $E$ is the internal energy per unit volume of the detonation products, and $w, A, B, R_{1}$, and $R_{2}$ are material constants. The corresponding parameters of the state equation of the explosive are shown in Table 10.

2.6.2. State Equation of Air. The *EOS_LINEAR_POLYNOMIAL state equation was used to simulate the properties of air in the explosion process [33]. The state equation can be written as follows:

$$
P=C_{0}+C_{1} \mu+C_{2} \mu^{2}+C_{3} \mu^{3}+\left(C_{4}+C_{5} \mu+C_{6} \mu^{2}\right) E,
$$

where $\mu=(1 / V)-1, P$ is the detonation pressure, $E$ is the internal energy per unit volume of the detonation products, and $C_{0}-C_{6}$ are the parameters of the state equation. For air, $C_{0}=C_{1}=C_{2}=C_{3}=C_{6}=0$ and $C_{4}=C_{5}=0.4$. The corresponding parameters of the state equation of air are shown in Table 11.

\subsection{FEM Model Establishment}

2.7.1. Geometric Model and Boundary Conditions. To simulate the real dynamic response of a column under near-field blast loading, the boundary conditions were determined as follows. The tops and bottoms of the two CFST columns were constrained as fixed ends. Based on previous reports [34, 35] and the conditions of the experiments, the air region was defined as follows. The columns were surrounded by a rectangular box filled with air. The box boundaries on the two sides and behind the column were $300 \mathrm{~mm}$ from the outer surface of the column. The top boundary of the air was even with the top of the column, and the bottom boundary of the air was even with the ground. A rigid reflecting plane was added at the bottom of the model to simulate the shock wave reflection from the ground. The model geometry is shown in Figure 8.

2.7.2. Finite Element Model. SOLID164 units were selected to represent all objects, including the columns, air, and explosive, to match closely with the experiment. Using LSDYNA, a multimaterial, arbitrary Lagrangian-Eulerian

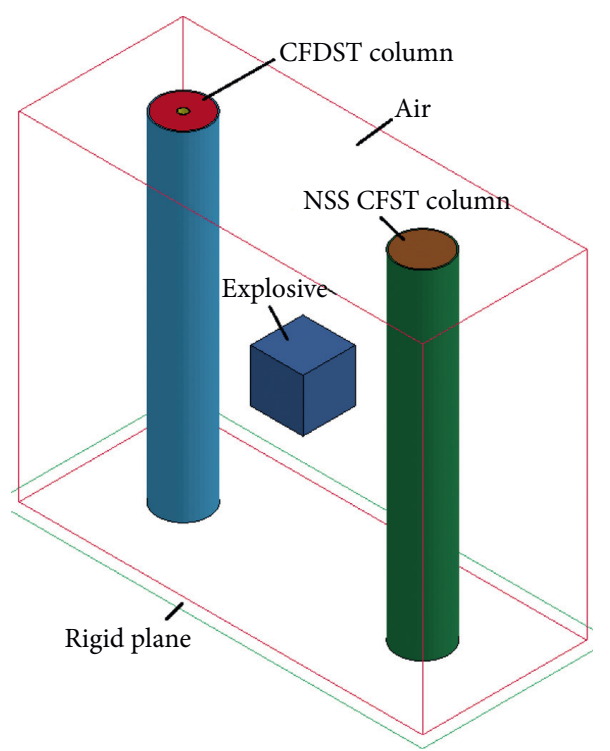

Figure 8: Sketch of geometric model.

finite element method with fluid-structure coupling was adopted to simulate the blast load exerted on the CFST columns. Considering the instantaneity of the blast loading, the surfaces between the steel tube units and infilled concrete units were set as fixed contacts. To determine a reasonable element size to simulate the explosion wave transmission, mesh sensitivity analyses were implemented based on different element sizes of 10, 20, 30, 40, and $60 \mathrm{~mm}$. All mesh sensitivity analysis results ( $0.5 \mathrm{~ms}$ after explosion) are shown in Figure 9. The peak pressures decreased as the element sizes were increased from 10 to $60 \mathrm{~mm}$. Furthermore, the shape of the wave front changed from hemispherical to ellipsoidal when the element sizes were increased from 10 to $60 \mathrm{~mm}$. The results of the mesh sensitivity analysis show that the accuracy of simulation decreased when the element size increased beyond $30 \mathrm{~mm}$. Considering the size effect of the mesh resolution, the efficiency, and the requirement of node sharing [36], the element size was selected as $20 \mathrm{~mm}$. Thus, the total number of SOLID164 cell units in the finite element model was 534,050, and the total simulation time was set to $20 \mathrm{~ms}$. The finite element model is shown in Figure 10.

2.8. Numerical Simulation Results. The results of the numerical simulations of the CFDST and NSS CFST columns are shown in Figures 11 and 12, respectively. Bending deformation on the front middle surfaces of the two kinds of 


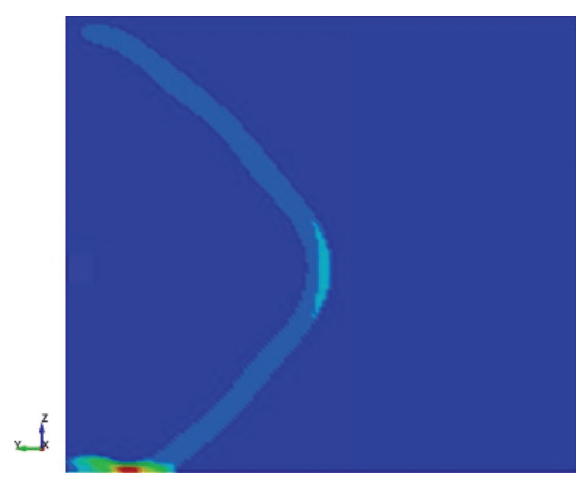

(a)

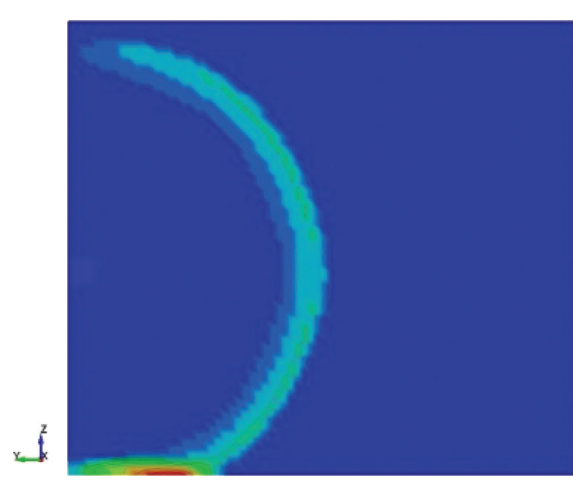

(c)
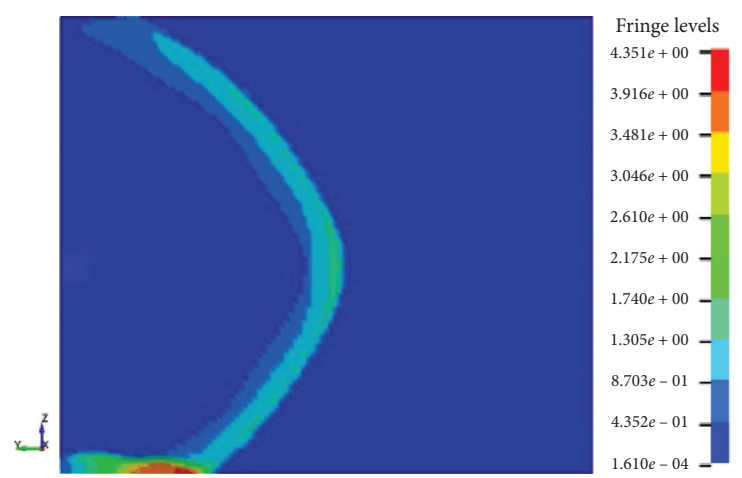

(b)
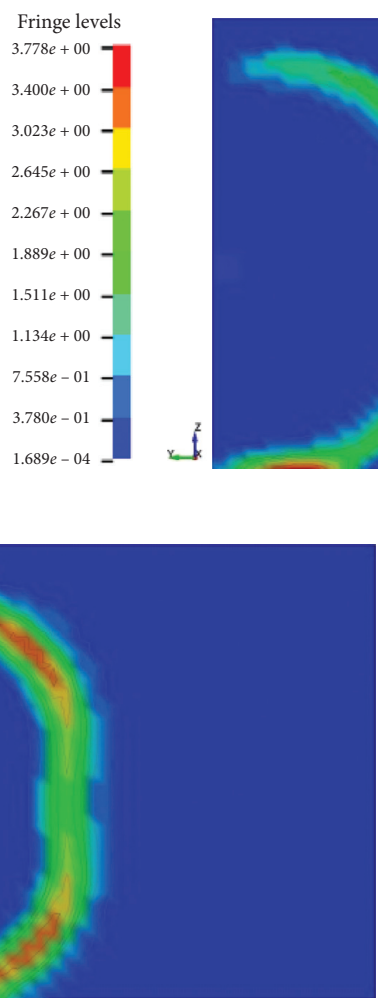

Fringe levels
$2.471 e+00$
$2.224 e+00$
$1.977 e+00$
$1.729 e+00-$
$1.482 e+00-$
$1.235 e+00-$
$9.884 e-01-$
$7.413 e-01-$
$4.943 e-01-$
$2.472 e-01$
$1.894 e-04$

(d)

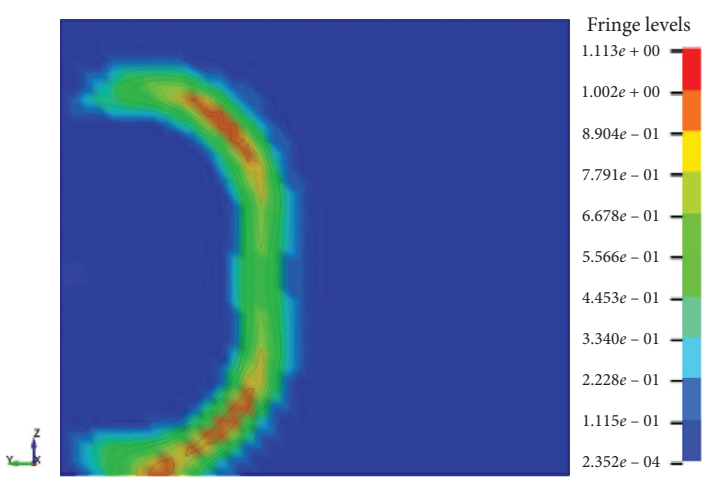

(e)

FIGURE 9: Results of presimulation with different element sizes (0.5 ms after explosion). (a) Element size of $10 \mathrm{~mm}$. (b) Element size of $20 \mathrm{~mm}$. (c) Element size of $30 \mathrm{~mm}$. (d) Element size of $40 \mathrm{~mm}$. (e) Element size of $60 \mathrm{~mm}$.

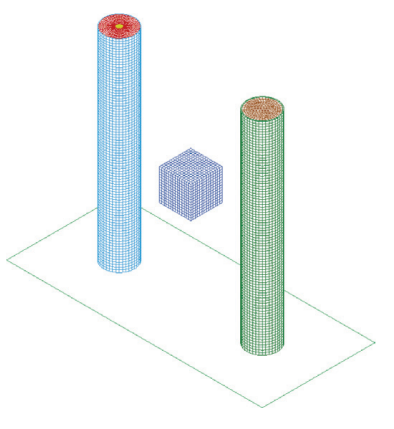

(a)

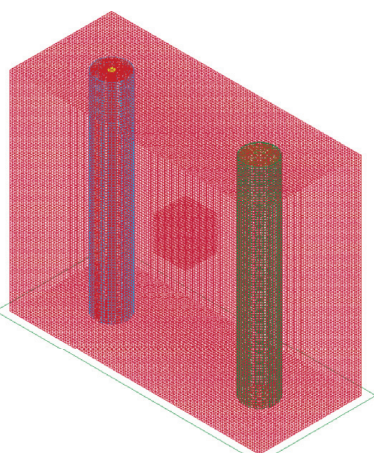

(b)

Figure 10: Finite element model. (a) Finite element model of columns and explosive. (b) Total finite element model. 
CFST columns was evident. The deformation of the composite hollow section was greater than that of the normal solid section. To compare the deformation amounts of the two kinds of CFST columns further, the results of the two columns are shown side by side in Figure 13.

Comparing the numerical simulation results with the bending deflection values of the two columns measured in the explosion experiments, the accuracies of the simulations were determined. The front middle surface deformation amounts of the two columns reached stable values after $2 \mathrm{~ms}$ in the numerical simulation. As shown in Figure 11, the simulated bending deflection of the CFDST column was $211.21 \mathrm{~mm}$, and the experimental value was $195 \mathrm{~mm}$, corresponding to an error of $7.8 \%$. As shown in Figure 12, the simulated bending deflection of the NSS column was $123.29 \mathrm{~mm}$, and the experimental result was $135 \mathrm{~mm}$, corresponding to an error of $8.7 \%$. The two errors were less than $10 \%$. Comparing Figures 7 and 13, the deformation of the columns in the simulation was much more localized than that in the experiments. The reasons for the errors and differences between the simulation and experimental results are as follows. First, there were differences in the environments. The conditions were ideal in the numerical simulations, but the explosion experiment was affected by factors such as the site conditions (i.e., the sizes of the air regions, the ground reflection conditions, and deviations from ideal adiabatic conditions) and the measurement accuracy of the deflection amounts of the columns. Second, there were differences in the constraint conditions. To implement fixed constraints of the columns, professional reaction frames were used in the explosion experiments, but the bolts used to fix the columns could be deformed or displaced. In the simulations, the fixed constraints of columns were fully implemented. Based on the error, the differences between the experiment and simulation conditions, such as the constraint conditions, the ground reflection conditions, and the ranges of the air regions, were acceptable, and the numerical simulations for the two kinds of CFST columns under the near-field explosion were reasonable. Thus, the numerical model could be used to perform further damage evaluation research for the two kinds of CFST columns.

\section{Analysis and Evaluation}

3.1. Deformation of Column Surface Facing Explosive. The results of the in-situ explosion experiments and numerical simulations showed that under the near-field blast loading with a scaled distance of $0.14 \mathrm{~m} / \mathrm{kg}^{1 / 3}$, the two kinds of columns were damaged on the surface facing the explosive. Greater plastic deformation occurred on the front middle surfaces of the two kinds of columns. The deflection values of the CFDST column were greater than those of the NSS column, which indicated that the antiexplosion performance of the NSS CFST column was better than that of the CFDST column subjected to the same near-field blast loading for a small-scaled distance.

As the duration of the in-situ explosion experiment was short, the numerical method, which was validated by the comparison above, was used to obtain the typical dynamic parameters of the two different types of CFST columns under blast loading. The displacement-time curves of the bottom, middle, and top regions of the two columns were obtained from the simulations and are shown in Figures 14 and 15. Since the deformation changes of the two columns mainly occurred from 0 to $5 \mathrm{~ms}$, the curves in Figures 14 and 15 only show the results from the first $5 \mathrm{~ms}$. Because the positive direction of the blast wave propagation was defined as the direction perpendicular to the surface of the NSS CFST column facing the explosive, the displacement values of the CFDST column in Figure 14 are negative, and the displacement values of the NSS CFST column in Figure 15 are positive.

Figure 14 shows that for the CFDST column, the deformation amounts at the three positions of the surface facing the explosive were stable after $4 \mathrm{~ms}$. Furthermore, because of the constraints and the explosive position, the maximum deformation occurred in the middle of the column, and the minimum deformation occurred on both ends. The deformation amounts at the middle, top, and bottom were $211.21,6.38$, and $7.53 \mathrm{~mm}$, respectively. The reason the deformation at the bottom was slightly greater than that at the top was related to the reflection of the blast wave from the rigid plane during the simulation (to simulate the reinforced concrete slab buried in soil). Therefore, the deformation at the bottom was larger than that at the top due to the increase in the blast wave intensity. Figure 14 shows the process of deformation development. At the top and bottom, the slopes of the curves increased quickly from 0 to $3 \mathrm{~ms}$, after which they slowly increased until becoming stable. In the middle, the slopes of the curves increased quickly from 0 to $0.5 \mathrm{~ms}$, after which they increased slowly and finally became stable.

The deformation process for the NSS CFST column is shown in Figure 15, and the deformations of the three positions of the surface facing the explosive were stable after $3 \mathrm{~ms}$. As with the hollow column, the maximum deformation amount was located in the middle of the column, and the minimum deformation amounts were located at both ends. The deformation in the middle, top, and bottom sections were $123.29,5.56$, and $6.14 \mathrm{~mm}$, respectively. The deformation at the bottom was slightly greater than that at the top. The deformation development curves at the top and bottom are shown in Figure 15. The slopes of the curve increased quickly from 0 to $2 \mathrm{~ms}$, after which they increased slowly until becoming stable. At the middle, the slope of the curve increased quickly from 0 to $0.7 \mathrm{~ms}$, after which it increased slowly and finally became stable.

A comparison of the dynamic responses showed that the deformation distributions of the two columns were similar. The maximum was located in the middle of the column, and the minimum was located at the two ends. At the same time, due to the reflection of the rigid plane, the deformation amounts at the bottom points of the two kinds of columns were slightly greater than those at the top points. The difference was that the deformation response time of the CFDST column was shorter than that of NSS CFST column.

To compare the final deformation amounts of the surfaces of the two columns facing the explosive, the values in 


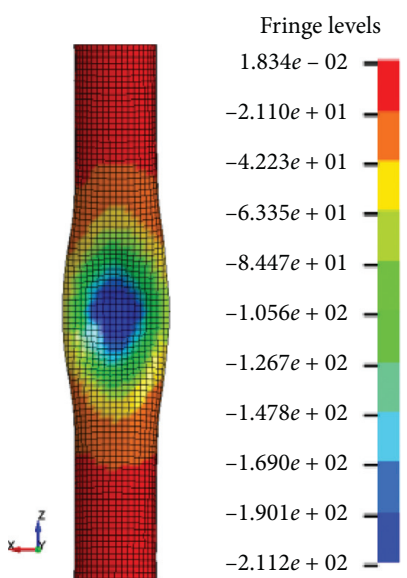

FIGURE 11: Result of simulation for CFDST column (scaled distance $=0.14 \mathrm{~m} / \mathrm{kg}^{1 / 3}$ ).

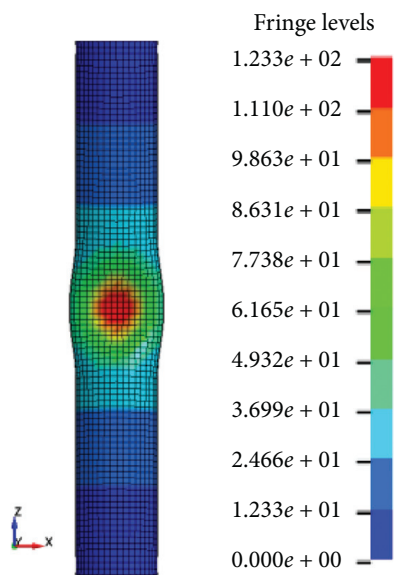

FIGURE 12: Simulation result for NSS CFST column (scaled distance $=0.14 \mathrm{~m} / \mathrm{kg}^{1 / 3}$ ).

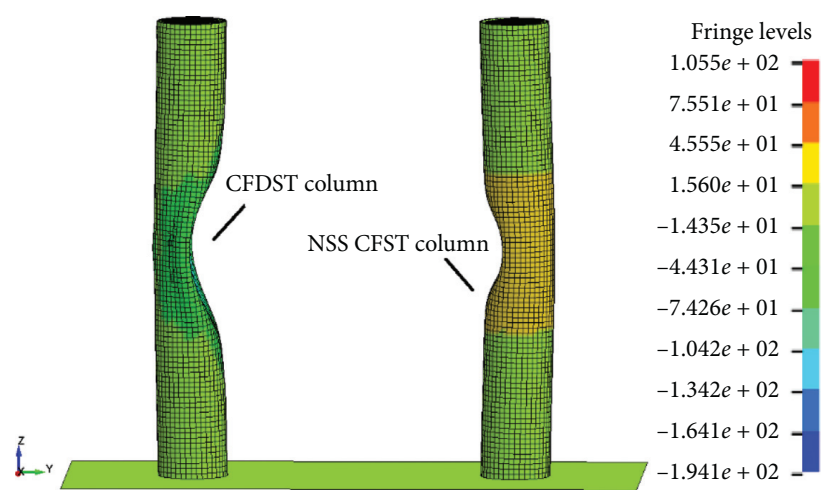

FIGURE 13: Side-by-side comparison of simulation results for two kinds of CFST columns (scaled distance $=0.14 \mathrm{~m} / \mathrm{kg}^{1 / 3}$ ).

the top, middle, and bottom regions are summarized in Table 12. From the data in Table 12, the deformation distribution of the surface facing the explosive was approximately symmetric with respect to the blasting centre. The final deformation values of the NSS CFST column were less than those of the CFDST column. This shows that the NSS column was superior to the CFDST column in terms of the antiexplosion performance.
3.2. Pressure-Time History Curve. With the numerical simulation results, the pressure-time history curves at the bottom, middle, and top points of the two kinds of CFST columns were obtained, as shown in Figure 16. With $50 \mathrm{~kg}$ of explosives and a scaled distance of $0.14 \mathrm{~m} / \mathrm{kg}^{1 / 3}$, the changes of the pressure-time curves at the three positions for the two kinds of columns were relatively consistent. The pressuretime curves at all three positions were characterized by steep 


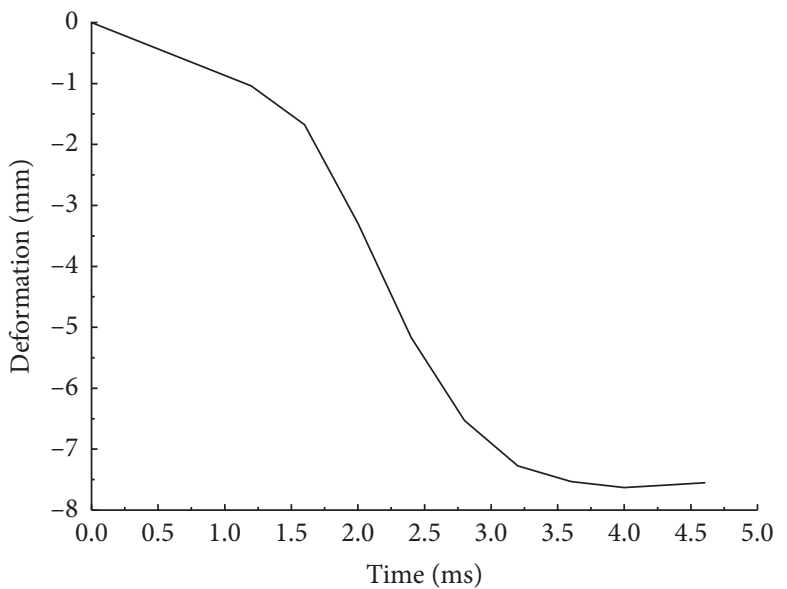

(a)

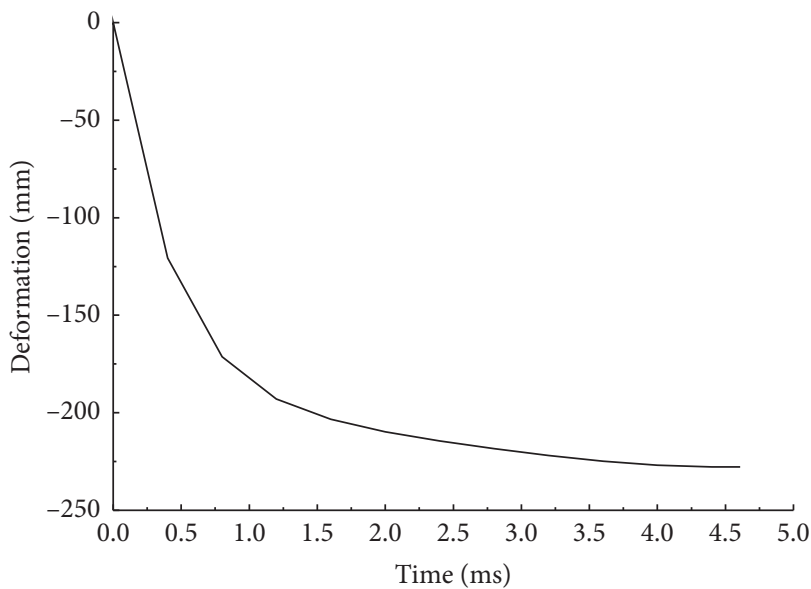

(b)

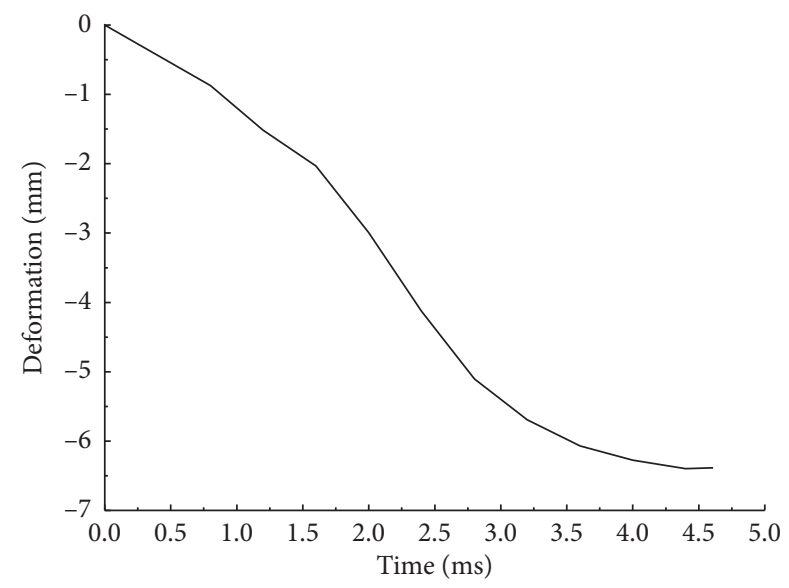

(c)

Figure 14: Deformation-time curve at different positions of the column surface facing the explosive. (a) Bottom of column. (b) Middle of column. (c) Top of column (CFDST section).

rises to peak values within short times after the explosion had initiated and then steep drops, after which they gradually approached zero.

As shown in Figure 16, the periods of positive pressure for both columns were approximately $1.5 \mathrm{~ms}$ at the bottom points, $1 \mathrm{~ms}$ at the middle points, and $1.5 \mathrm{~ms}$ at the top points. Thus, the positive pressure durations at the three positions facing the explosive were very similar.

As shown in Figure 16, the peak pressure values of the CFDST column were $18.72 \mathrm{MPa}$ at the bottom point, $176.05 \mathrm{MPa}$ at the middle point, and $4.17 \mathrm{MPa}$ at the top point. For the NSS column, the peak pressure values were 17.28 $\mathrm{MPa}$ at the bottom point, $176.01 \mathrm{MPa}$ at the middle point, and $4.25 \mathrm{MPa}$ at the top point. Thus, the distribution of the pressure peak values for the two different CFST columns can be summarized as follows. Both middle values were greater than the bottom and top values. The pressure peak values at middle points were about 8 times greater than those at the bottom points and 41 times greater than those at the top points. Based on this analysis, severe damage occurred in the middle of column surface facing the explosive. Thus, the damage assessment of the two column specimens should focus on the deformation of the middle of the column surface facing the explosive.

Furthermore, the times of the peak pressure for three different positions of the two column types were $0.4 \mathrm{~ms}$ at the bottom point, $0.2 \mathrm{~ms}$ at the middle point, and $0.3 \mathrm{~ms}$ at the top point, which showed that the amount of time for the blast waves to reach the bottom, middle, and top of each column were almost the same.

Therefore, it was concluded that the blast wave had the strongest effect on the middle points of the two columns. The effect was lower at the bottom points and the smallest at the top points of the columns. The numerical simulation results were consistent with the experimental results. 


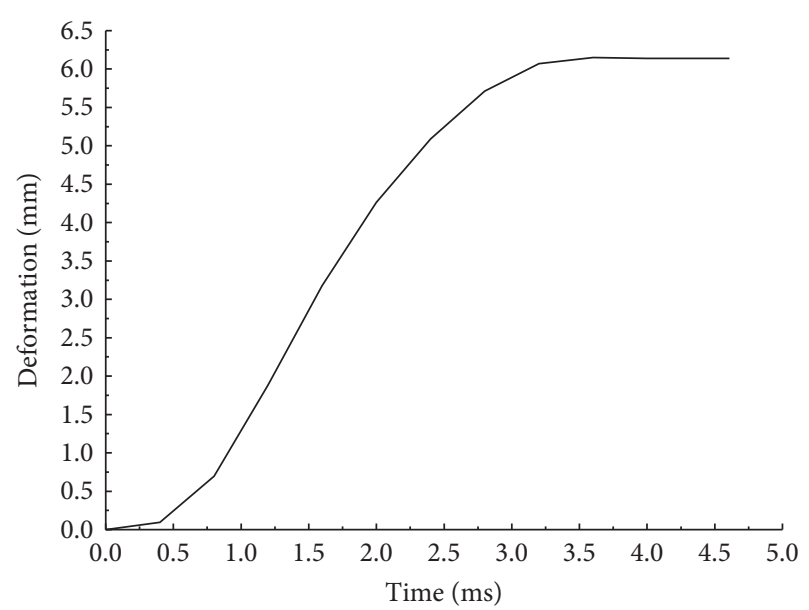

(a)

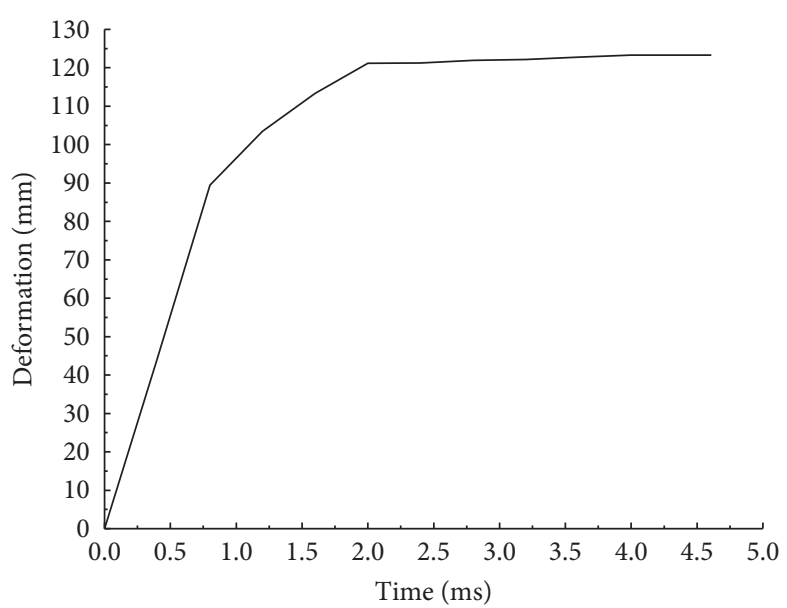

(b)

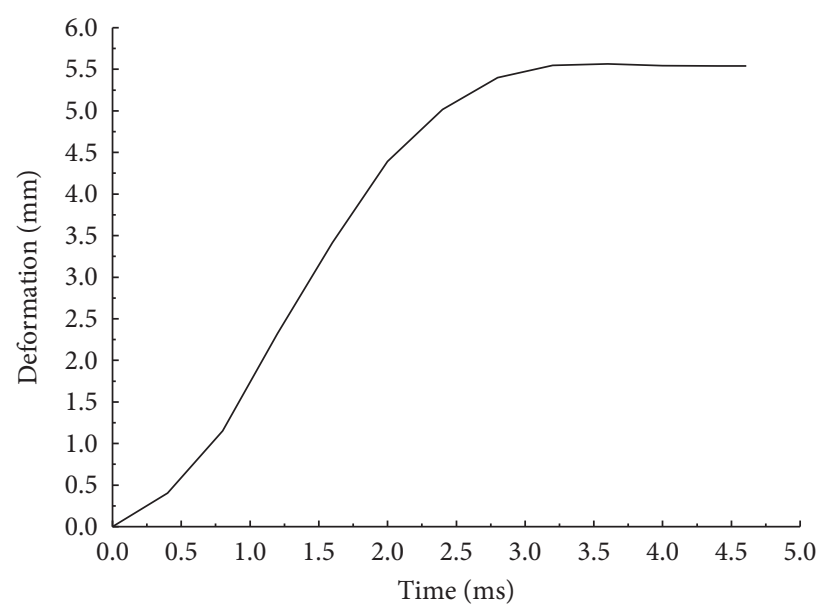

(c)

Figure 15: Deformation-time curves at different positions of the column surface facing the explosive. (a) Bottom of column. (b) Middle of column. (c) Top of column (NSS).

TABLE 12: Final deformation values at different positions on the column surface facing the explosive.

\begin{tabular}{lcc}
\hline Position & & Values $(\mathrm{mm})$ \\
& CFDST section & NSS \\
\hline Bottom & -7.53 & 6.14 \\
Middle & -21.21 & 123.29 \\
Top & -6.38 & 5.56 \\
\hline
\end{tabular}

3.3. Damage of Inner Concrete. To investigate the damage of the concrete filled in the steel tube under near-field blast loading, the *MAT_ADD_EROSION keyword was added to the numerical model based on the ultimate tensile strain of the concrete (which was $0.2 \times 10^{-2}$ ). The damage and failure of the concrete filled in the two columns are shown in Figure 17.

For a scaled distance of $0.14 \mathrm{~m} / \mathrm{kg}^{1 / 3}$, the concrete in both columns became damaged, especially in the middle region facing the explosive. From the analysis of the damage of the concrete, especially through the comparison of the missing concrete elements in both columns shown in Figure 17, it was determined that there was slightly less damage to the concrete in the CFDST column (left side of figure) than that in the NSS column (right side of figure). Since the two column specimens were not cut open for examination, all the results of the inner concrete damage from the simulation must be calibrated with experimental results in future research [37]. The simulated damage of the inner concrete was based on a predefined concrete constitutive model. Although this was not calibrated with the experimental data, the relative inner concrete damage of the two columns should be comparable because the same constitutive model was used for both. 


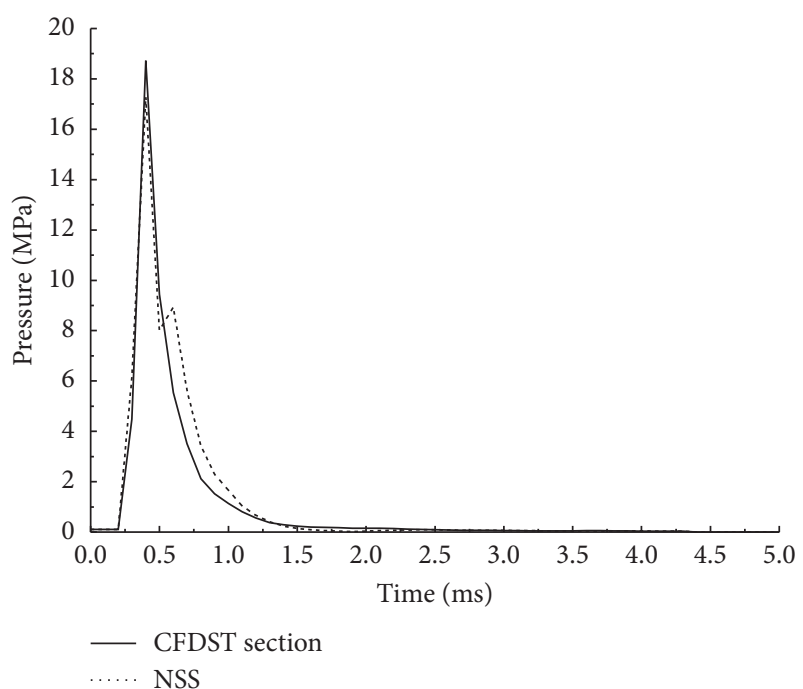

(a)

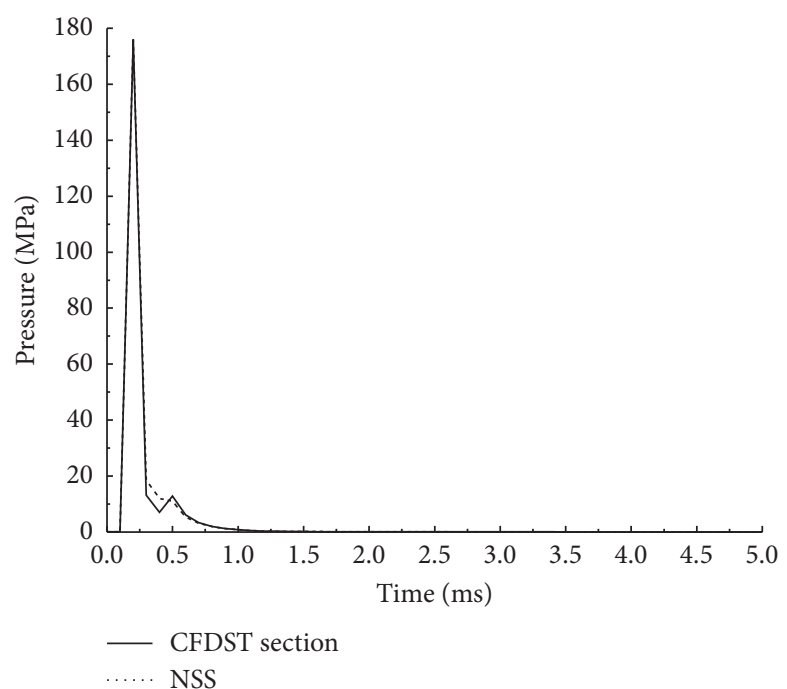

(b)

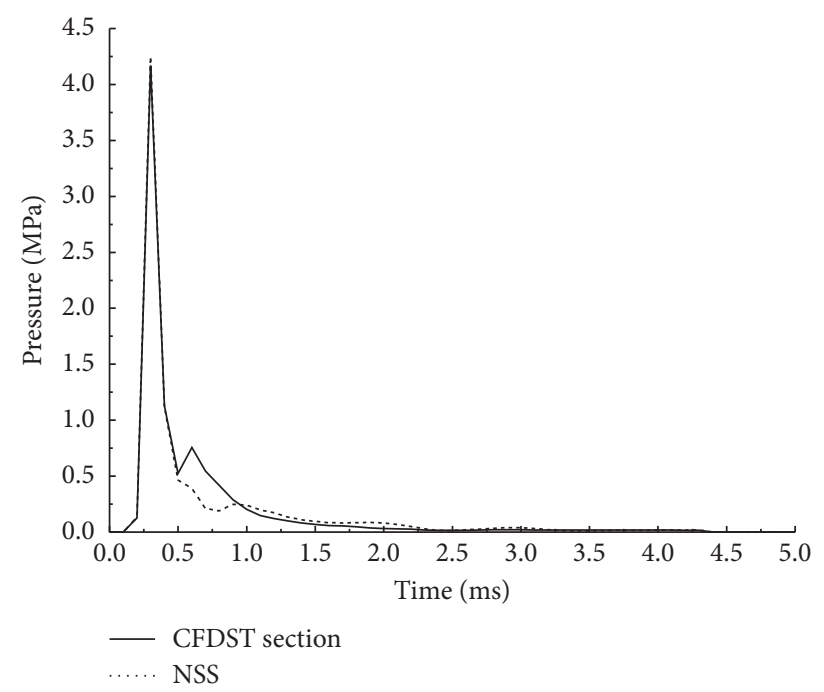

(c)

Figure 16: Pressure-time curves at different positions on the column surface facing the explosive. (a) Bottom of column. (b) Middle of column. (c) Top of column.

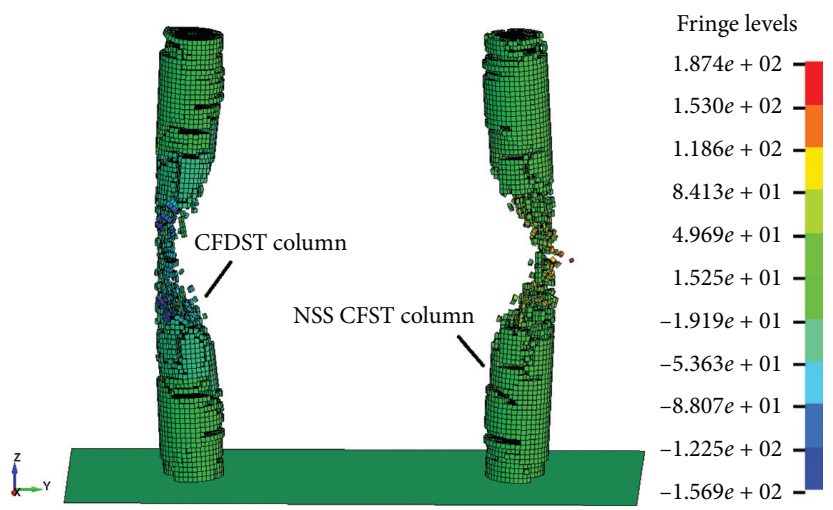

FIGURE 17: Damage of inner concrete of two different column types. 


\section{Results and Discussion}

4.1. Damage Assessment Criterion. Damage assessment plays an important role in the evaluation of the stability and strength of a structural member. At present, the modes of failure for column members can be divided into maximum displacement, maximum stress, maximum strain, and vertical residual bearing capacity [38, 39]. The main principle for determining the damage assessment criteria is that the characteristics of the CFST columns related to the criteria should be easily obtained by experimental or numerical simulation methods, and the criteria should be easy to use in practical projects. According to the UFC 3-340-02 standard, under blast loading, the allowable value of the elastic-plastic rotation angle at the support of the structural member is $2^{\circ}$ [40]. It is known from material mechanics theory that the rotation angle at the support of the column can be converted into deflection at the middle of the column. Thus, if the deflection of the middle of the column does not exceed 1/60 times the height of the column under the blast loading, the column can be considered to be safe. In this paper, a pressure-impulse damage assessment criterion for the deflection of two CFST columns under the condition of fixedend constraints was established based on the relationship between the deflection and the height of the column.

Two damage assessment criteria for CFST columns can be simply expressed as follows. If the deflection is less than $1 /$ 60 times the height of the column, the column can be determined to be safe. If the deflection is more than 1/60 times the height of the column, the column can be determined to be unsafe. A schematic of the deflection of the column is shown in Figure 18. The final middle deformation values of the two columns shown in Table 12 can be used as the deflection values.

4.2. Establishment of Pressure-Impulse Diagram (P-I Curve) for Two Different Columns. The established finite element models of the two kinds of CFST columns were adjusted several times to obtain the critical pressure and impulse. After each numerical simulation, the displacement-time curve of the element was obtained by selecting the element located in the geometric centre of the column surface facing the explosive. $f$ denotes the deflection of the column, and $L$ denotes the height of the column. The pressure and impulse data obtained from many numerical simulations were plotted in the pressure-impulse (P-I) plane. The critical values of the pressure and impulse were determined from the data, which agreed with the condition of $f=L / 60$. The damage diagram, i.e., the P-I curves, for the CFDST column and the NSS CFST column were obtained, as shown in Figures 19 and 20, respectively.

The P-I curves established in Figures 19 and 20 show that the P-I plane was divided into two regions. If the $P$ and $I$ data fall to the left of the curve, the deflection of the column is less than $L / 60$, and the deformation is still within the safe range. Thus, the column can be judged to be safe. If the combined data of $P$ and $I$ fall to the right of the curve, the deflection of the column is greater than $L / 60$, and the column can be judged to be unsafe. If the $P$ and $I$ data fall on the curve, corresponding to a critical state, the column should be judged to be unsafe. For example, according to the near-field explosion experiment and simulation for the CFDST column, the $P$ and $I$ data $(P=176.05 \mathrm{MPa}$ and $I=22.66 \mathrm{MPa} \cdot \mathrm{ms})$ fell to the right of the curve shown in Figure 19, and thus, the CFDST column could be judged to be unsafe under the blast loading in the experiment. Furthermore, for the NSS CFST column, the $P$ and $I$ data $(P=176.01 \mathrm{MPa}$ and $I=23.37 \mathrm{MPa} \cdot \mathrm{ms})$ also fell to the right of the curve shown in Figure 20. Thus, the NSS CFST column was in an unsafe state.

To compare the differences between the two P-I curves of the different columns, the curves are plotted in the same coordinate system in Figure 21. The P-I curves of the two columns had the same trends, but the curve of the NSS column was slightly higher than that of the CFDST column. The results showed that for the NSS CFST column, the probability of the $P$ and $I$ data falling to the left of the curve was slightly higher. This means that the antiexplosion performance of the NSS CFST column was better than that of CFDST column.

4.3. Mathematical Formula for Pressure-Impulse Diagram (P-I Curve). To provide a clear mathematical interpretation for the P-I curves of the two columns, the P-I curves in Figures 19 and 20 were fitted with mathematical formulae. Through the analysis of the data, $I$ and $P$ were found to follow an approximately natural logarithmic relationship. Thus, the P-I curves of the two columns can be expressed as follows:

$$
P=A-B \ln I+C,
$$

where $P$ is the peak pressure of the blast wave, $I$ is the impulse of the blast wave, and $A, B$, and $C$ are three real constants, which are related to the damage of the columns. The fitting results of equation (5) are shown in Figures 22 and 23 .

Figures 22 and 23 show that the curves drawn by the fitting formula were in good agreement with the numerical simulation results. Therefore, generalizing equation (5), the damage assessment criteria for the two kinds of CFST columns with deflection values of the surface facing the explosion were established. For example, according to the analyses and data in this paper, taking the deflection $f=$ $L / 60$ as the safety criterion, the deflection value was calculated as $30 \mathrm{~mm}$. Based on equation (5), the following fitted equation was determined, which can be used to determine the damage of the CFDST column:

$$
P=138.45-70.63 \ln (I-0.5) \text {, }
$$

where $A=138.45, B=70.63$, and $C=-0.5$.

Equation (7) was similarly determined, and it can be used to determine the damage of the NSS CFST column:

$$
P=149.03-70.63 \ln (I-0.5),
$$

where $A=149.03, B=70.63$, and $C=-0.5$. 


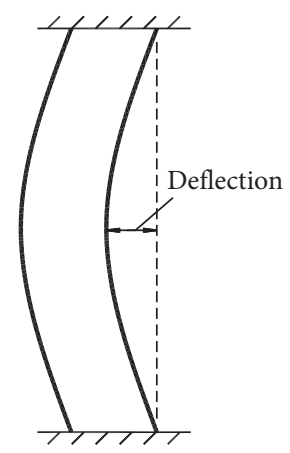

FIGURE 18: Schematic view of column deflection.

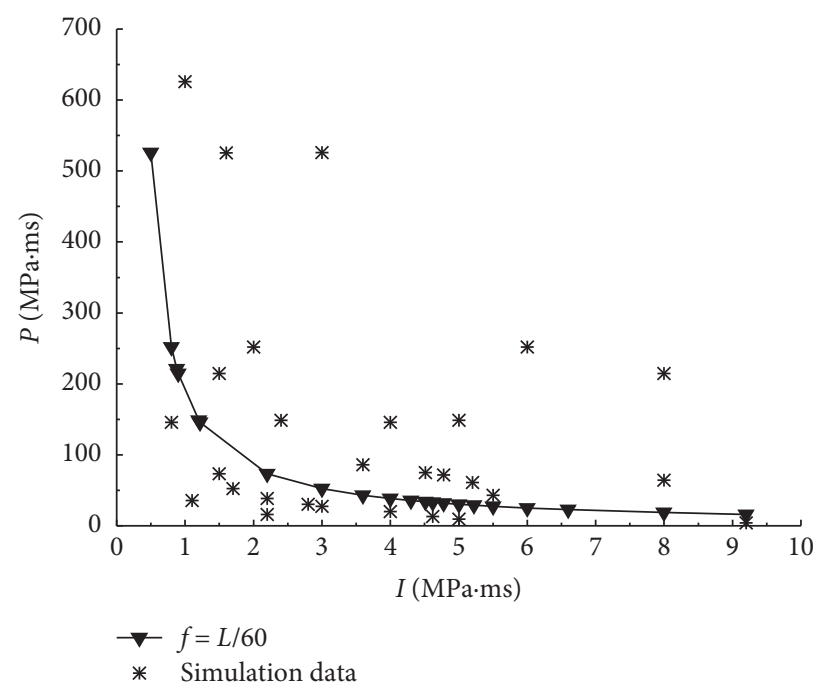

Figure 19: Pressure-impulse (P-I) curve of the CFDST column.

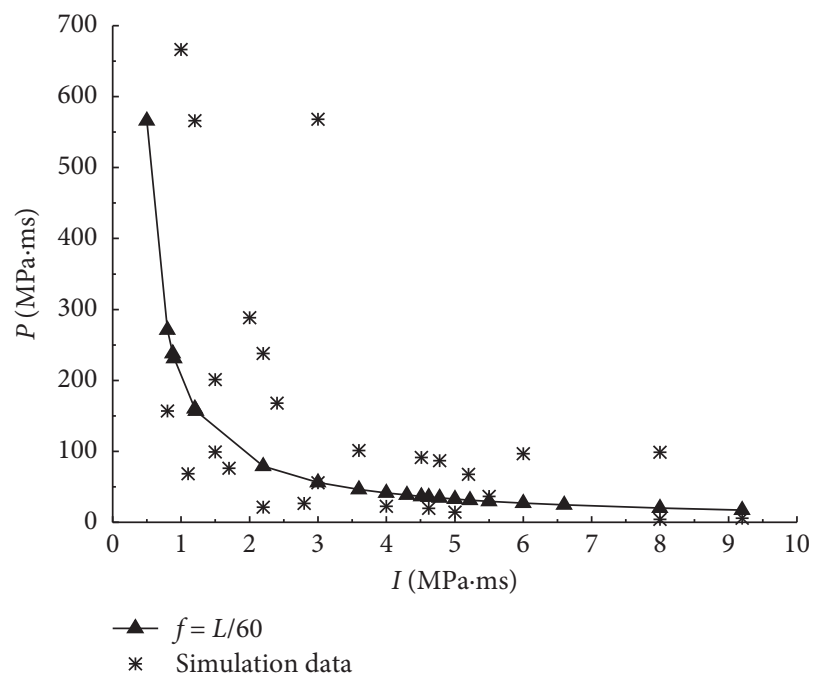

Figure 20: Pressure-impulse (P-I) curve of the NSS CFST column.

Equations (6) and (7) are suitable for the explosion damage assessment of the CFDST section and NSS CFST columns, respectively, under the fixed-end constraints and design parameters presented above (only for the two specimens). Similarly, the fit pressure-impulse (P-I) curves in Figures 22 and 23 can be used to evaluate the safety of these two CFST column cross sections with the design parameters presented above. The corresponding P-I curves and formulae for other CFST columns with different constraints and design parameters (e.g., with different cross sections) 


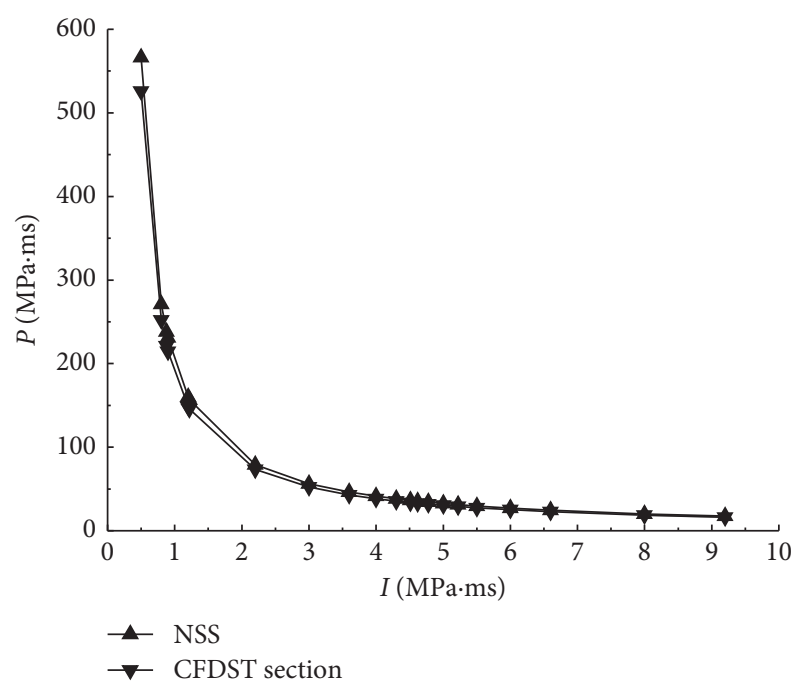

Figure 21: Pressure-impulse (P-I) curve of the NSS CFST column and CFDST column.

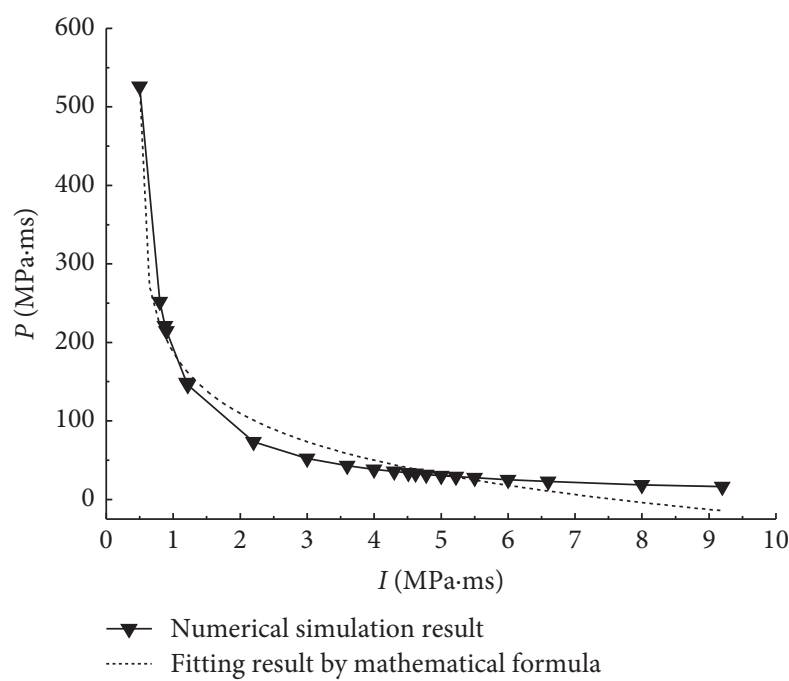

FIgUre 22: Comparison between fit pressure-impulse (P-I) curve and the numerical simulation for the CFDST column.

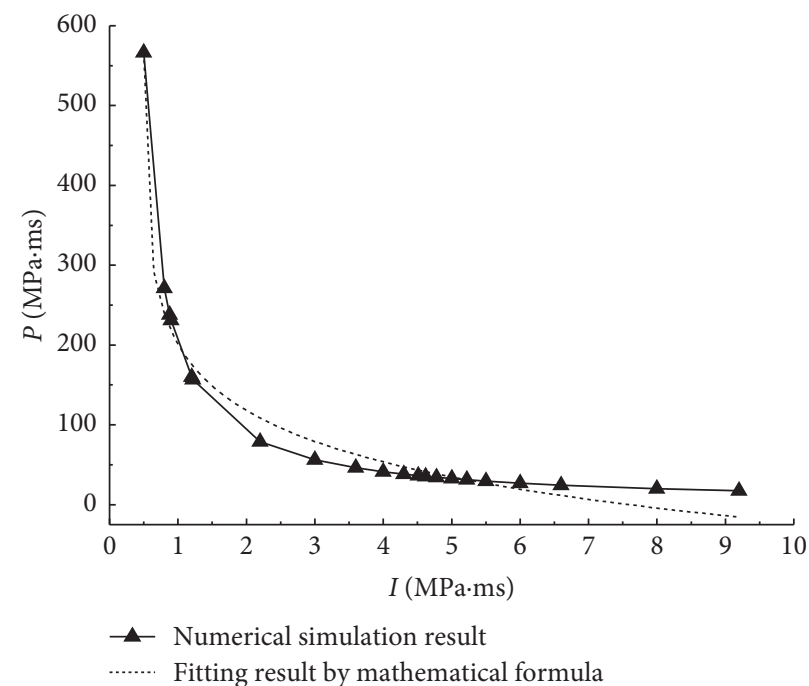

Figure 23: Comparison between fit pressure-impulse (P-I) curve and numerical simulation for the NSS CFST column. 
subjected to near-field blast loading can be deduced using the methods summarized in this paper.

\section{Conclusions}

In this paper, the dynamic responses and damage assessment of normal solid-section and CFDST columns subjected to near-field blast loading were studied by means of an explosion experiment and numerical simulations. The following conclusions were obtained.

(1) From the bending deformation values and the P-I curves, which were obtained by experiments and numerical simulations, the deformation of the NSS CFST column was smaller than that of the CFDST column under the same near-field blast loading because of the high filling ratio of concrete. The antiexplosion performance of the NSS column was better than that of the CFDST column under the conditions described above.

(2) Under the same blast loading conditions, when the blast centre was equal to the middle height of the column, the blast shock wave caused the most intense damage at the middle points of the two columns, and the amount of damage at the bottom points of the two columns was greater than those at the top points.

(3) Based on the analysis of the structural differences between the two columns, the inner concrete damage of the CFDST column subjected to the same blast loading was lower than that of the NSS CFST column because the inner steel tube of the CFDST column increased the overall stiffness of the column.

(4) Damage assessment criteria for the CFDST section and NSS CSFT columns were established based on pressure-impulse damage theory. With the damage assessment criterion, the P-I curves and mathematical formulae were derived based on the ratio between the deflection and the height of the column facing the explosive under the fixed constraints. Furthermore, the safety performance of other different CSFT column cross sections subjected to near-field blast loading can be evaluated using this damage assessment criterion.

\section{Data Availability}

The experimental and numerical simulation data used to support the findings of this research are included within the manuscript.

\section{Conflicts of Interest}

The authors declare that there are no conflicts of interest regarding the publication of this paper.

\section{Acknowledgments}

This work was financially supported by the Natural Science Foundation of China (51674200 and 51878056) and the Natural Science Basic Research Program of Shaanxi Province (2020JM-536 and 2019JQ-466). The authors thank LetPub (http://www.letpub.com) for its linguistic assistance and scientific consultation during the preparation of this manuscript.

\section{References}

[1] H. Huang, Z. Tao, and L. H. Han, "Mechanism of concretefilled double-skin steel tubular columns subjected to axial compression," Industrial Construction, vol. 36, no. 11, pp. 11-14, 2006.

[2] H. W. Wang, G. L. Xu, and S. T. Zhong, "Study on influence of hollow ratio to breaking capacity of H-CFST," Engineering Mechanics, vol. 24, no. 10, pp. 112-118, 2007.

[3] E. M. Güneyisi, A. Gültekin, and K. Mermerdaş, "Ultimate capacity prediction of axially loaded CFST short columns," International Journal of Steel Structures, vol. 16, no. 1, pp. 99-114, 2016.

[4] H. R. Kumar, K. U. Muthu, and N. S. Kumar, "Study on predicting axial load capacity of CFST columns," Journal of The Institution of Engineers (India): Series A, vol. 99, no. 1, pp. 133-140, 2018.

[5] N. Li, Y. Y. Lu, and S. Li, "Experimental study on self-stressing and self-compacting concrete-filled circular steel tube short columns subjected to axial compression," Journal of Building Structures, vol. 40, no. 11, pp. 162-171, 2019.

[6] J. L. Ou and Y. B. Shao, "Static strength of concrete filled circular CFRP-steel tubular stubs under axial compression," Engineering Mechanics, vol. 36, no. 10, pp. 180-188, 2019.

[7] K. M. A. Hossain and K. Chu, "Confinement of six different concretes in CFST columns having different shapes and slenderness," International Journal of Advanced Structural Engineering, vol. 11, no. 2, pp. 255-270, 2019.

[8] J.-H. Zhang, B. Chen, and S.-Y. Jiang, "A simplified model to predict blast response of CFST columns," Journal of Central South University, vol. 24, no. 3, pp. 683-691, 2017.

[9] H. Hao, H. K. Cheong, and S. J. Cui, "Numerical study of dynamic buckling of steel columns subjected to underground explosion," Engineering Materials, vol. 233, no. 1, pp. 211-216, 2002.

[10] K. M. Lim, H. O. Shin, D. J. Kim, Y. S. Yoon, and J. H. Lee, "Numerical assessment of reinforcing details in beam-column joints on blast resistance," International Journal of Concrete Structures and Materials, vol. 10, no. 3, pp. S87-S96, 2016.

[11] H. A. Thairy, "A modified single degree of freedom method for the analysis of building steel columns subjected to explosion induced blast load," International Journal of Impact Engineering, vol. 94, pp. 120-133, 2016.

[12] Z.-X. Li, B. Zhong, Y. Shi, and J.-B. Yan, "Nonlocal formulation for numerical analysis of post-blast behavior of RC columns," International Journal of Concrete Structures and Materials, vol. 11, no. 2, pp. 403-413, 2017.

[13] Y. L. Ma, B. Xie, D. Z. He, and J. X. Nie, "Numerical analysis on blasting response of circular concrete-filled steel tubes," Journal of Wuhan University of Technology, vol. 32, no. 14, pp. 120-124, 2010. 
[14] Y. C. Shi, Dynamic response and damage mechanism of reinforced concrete structures under blast loading, Ph.D. thesis, Tianjin University, Tianjin, China, 2009.

[15] J. Y. Xue, Y. C. Liu, and T. S. Liu, "Experimental study on antiknock performance of concrete filled steel tube," Journal of North University of China (Natural Science Edition), vol. 32, no. 6, pp. 786-790, 2011.

[16] Y. Cui, J. H. Zhao, C. G. Zhang, and S. S. Sun, "Research on pressure distribution of blast wave on the surface of CFST column based on explosion test and numerical simulation," Journal of Beijing University of Technology, vol. 40, no. 12, pp. 1828-1836, 2014.

[17] S. C. Xu, Z. X. Liu, and C. Q. Wu, "Field blast test and numerical simulation of ultra-high performance steel fiber reinforced concrete-filled double skin steel tube column under blast loading," Explosion and Shock Wave, vol. 37, no. 4, pp. 650-660, 2017.

[18] G. B. Nica, M. Lupoae, F. Pavel, and C. Baciu, "Numerical analysis of RC column failure due to blast and collapse scenarios for an irregular RC-framed structure," International Journal of Civil Engineering, vol. 16, no. 9, pp. 1125-1136, 2018.

[19] W. X. Chen, Z. K. Guo, H. H. Zou, and T. Zhang, "Near-field blast-resistant test of reactive powder concrete filled steel tubular column after exposure to standard fire," Engineering Mechanics, vol. 34, no. 1, pp. 180-191, 2017.

[20] S. S. Sun, J. H. Zhao, S. H. He, Y. Cui, and Y. Liu, "Dynamic response of concrete-filled steel tube piers under blast loadings," Engineering Mechanics, vol. 35, no. 5, pp. 27-35, 2018.

[21] Y. Liu, J.-B. Yan, and F.-L. Huang, "Behavior of reinforced concrete beams and columns subjected to blast loading," Defence Technology, vol. 14, no. 5, pp. 550-559, 2018.

[22] F. R. Zhang, C. Q. Wu, Z. X. Li, and X. L. Zhao, "Residual axial capacity of CFDST columns infilled with UHPFRC after closerange blast loading," Thin-Walled Structures, vol. 96, pp. 314-327, 2016.

[23] H. W. Wang, C. Q. Wu, L. Z. Yang, Y. Zhou, and P. Li, "Experimental research on residual bearing capacity of fullscale concrete-filled steel tubular column after explosion," Journal of Building Structures, vol. 37, no. 5, pp. 155-160, 2016.

[24] W. Chen, Z. Zhou, H. Zou, and Z. Guo, "Predictions of residual carrying-capacities for fire and near-field blast-damaged reactive powder concrete-filled steel tube columns," International Journal of Protective Structures, vol. 9, no. 4, pp. 525-553, 2018.

[25] H. H. Zou, W. X. Chen, Z. K. Guo, and Z. X. Zhou, "Experimental studies on residual carrying-capacities of fire and blast-damaged RPC-FST columns," Engineering Mechanics, vol. 36, no. 7, pp. 184-196, 2019.

[26] M. P. Rutner and D. A. Vaccari, "Preliminary and time-efficient vulnerability assessment of structural columns subjected to blast loading," Engineering Structures, vol. 128, pp. 55-66, 2016.

[27] M. Mohammad, A. H. Mohammad, B. Chiara, and B. Abdolhossein, "Numerical damage evaluation assessment of blast loaded steel columns with similar section properties," Structures, vol. 20, pp. 189-203, 2019.

[28] D. K. Thai, T. H. Pham, and D. L. Nguyen, "Damage assessment of reinforced concrete columns retrofitted by steel jacket under blast loading," The Structural Design of Tall and Special Buildings, vol. 29, no. 1, pp. 1-15, 2019.

[29] B. E. Gel'fand, I. M. Voskoboinikov, and S. V. Khomik, "Recording the position of a blast-wave front in air," Combustion, Explosion, and Shock Waves, vol. 40, pp. 734-736, 2004.
[30] X. Zhou, Test and Evaluation for Damage Effectiveness of Missile, National Defense Industry Press, Beijing, China, 2014.

[31] J. O. Hallquist, LS-DYNA Keyword User's Manual, Livermore Software Technology Corporation (LSTC), Livermore, CA, USA, 2007.

[32] S. Q. Shi, J. G. Kang, and M. Wang, Engineering Applications of ANSYS/LS-DYNA in Explosion and Shock Field, China Architecture \& Building Press, Beijing, China, 2011.

[33] H. Q. Lu and W. Q. Liu, "Research on numerical simulation of blast wave in air," Journal of Wuhan University of Technology, vol. 31, no. 19, pp. 105-108, 2009.

[34] S. B. Li, Z. X. Dong, Y. J. Qi, and J. F. Jiao, "Numerical simulation on decay spread of blasting shock wave in different media," Journal of Vibration and Shock, vol. 28, no. 7, pp. 115-117, 2009.

[35] X. Yang, S. Q. Shi, and F. P. Chen, "Forecast and simulation of peak overpressure of TNT explosion shock save in the air," Blasting, vol. 25, no. 1, pp. 15-18, 2008.

[36] Y. Shi, Z. Li, and H. Hao, "Mesh size effect in numerical simulation of blast wave propagation and interaction with structures," Transactions of Tianjin University, vol. 14, no. 6, pp. 396-402, 2008.

[37] B. M. Luccioni, G. F. Aráoz, and N. A. Labanda, "Defining erosion limit for concrete," International Journal of Protective Structures, vol. 4, no. 3, pp. 315-340, 2013.

[38] TM5-1300, Structures To Resist the Effects of Accidental Explosion, United States Department of the Army, the Navy and the Air Force, Washington, DC, USA, 1990.

[39] M. Abedini, A. A. Mutalib, S. N. Raman, R. Alipour, and E. Akhlaghi, "Pressure-impulse (P-I) diagrams for reinforced concrete (RC) structures: a review," Archives of Computational Methods in Engineering, vol. 26, no. 3, pp. 733-767, 2019.

[40] UFC-3-340-02, Design of Structures to Resist the Effects of Accidental Explosions, US Army Corps of Engineers, Naval Facilities Engineering Command. Air Force Civil Engineer Support Agency, Department of the Army and Defense Special Weapons Agency, Washington, DC, USA, 2008. 